\title{
INFLUENCE OF INFORMATION TECHNOLOGIES ON TECHNICAL FITNESS OF STUDENTS IN SPORT-ORIENTED PHYSICAL EDUCATION
}

Kozina Zh. L. ${ }^{1}$, Ol'khovyj O. M. ${ }^{2}$, Temchenko V. A. ${ }^{2}$

${ }^{1}$ H.S. Skovoroda Kharkiv National Pedagogical University

${ }^{2}$ Kharkov National University

\begin{abstract}
Purpose: to determine influence of information technologies in sport-oriented physical education on technical fitness of students, practicing football indoors. Material: in the researches students (boys - $n=40$ ) of 1820 years' age participated. Standard tests on physical condition were used. For determination of motor skills and abilities we used: juggling with ball; kick in pre-set sector of goal; shuttle run 4 x 10 meters with dribbling; kick for distance. Results: structural model of sport-oriented students' physical education with application of information technologies has been formed. In the model all students are trained in sport-oriented academic groups by chosen kinds of sports (motor functioning). Such approach envisages holistic form of program material construction and unified algorithm of students' progress assessment. Conclusions: the wholeness of sport-oriented physical education's functioning is ensured at the account of application of information technologies. It permits to optimize motor skills' training process. In this case single form of building of program material is created.
\end{abstract}

Key words: students, sport, physical education, information technologies, football indoors.

\section{Introduction}

Intensification of educational process in higher educational establishments resulted in tendency to weakening of students' motor functioning. The researchers note that reduction of motor functioning negatively influence on students' physical condition, physical fitness and functional state [21, 22]. In this connection importance of students' health protection and strengthening is increasing [28, 31, 32, 33, 35].

Scientific-technical progress facilitated computerization of all spheres of life $[14,24,26]$. Such shifts have two sides of changes in life. Increase of communication opportunities owing to computer informational technologies is accompanied by rapid growth of quantity and quality of information in all spheres of life. Increase of time for motor functioning results in weakening of functional potentials and physical fitness of students $[2,6$, $8,10]$. Some authors think that usage of computer informational technologies permits to individualize physical education process and increase students' activity [6]. Useful and final result of it is increase of effectiveness of students' physical education.

At present a number of methodic on creation of complex image of structure and specificities of technicaltactic elements and exercises' fulfillment has been developed $[7,8,9,10]$. However, in sport-oriented physical education application of informational technologies shall differ from analogous technologies for qualified sportsmen $[1,3,4,5,15]$. It is connected with peculiarities and level of students' physical and special fitness. Application of informational technologies shall also comply with tasks of healthy life style formation and consider students' perception of presented information $[4,5,18,20]$.

In system of students' progress in discipline "Physical education" assessment it is purposeful to consider quality, expressed in presence of skills and abilities to fulfill physical exercises; ability to work independently at lessons and in extra-curriculum time [11-13]. In this connection it would be logical to assume that active mastering of informational technologies and their implementation in sport-oriented physical education shall facilitate effectiveness of educational process.

Purpose, tasks of the work, material and methods

The purpose of the works is to determine influence of information technologies in sport-oriented physical education on technical fitness of students, practicing football indoors.

Material and methods: experimental group was composed of 19 students, practicing football indoors; control - 21 students. At the beginning and at the end of academic year we conducted pedagogic testing for determination of physical and technical fitness. As tests we used standard tests for physical and technical fitness $[16,17,19,23,25,27,29,30]$. For determination of physical fitness we conducted pedagogic testing: forward 
bending from sitting position; shuttle run $4 \times 9$ meters; long jump from the spot; 100 meters' run; rising in sitting position from lying on back position; chin ups. For determination of motor skills and abilities we used: juggling with ball; kick in pre-set sector of goal; shuttle run $4 \times 10$ meters with dribbling; kick for distance.

In experimental group we used informational technologies for training of motor skills and abilities in football indoors. Control group was trained without informational technologies' application. Total duration of forming experiment was 9 months (2013-2014 academic year). All tested were informed about research and gave written consent for participation in the research. All researches were conducted in compliance with standards of Helsinki declaration, 2008.

The received data were processed with the help of program Microsoft Excel "Data analysis", SPSS. By each indicator we found mean arithmetic X, mean square deviation $\sigma$ (standard deviation), assessment of confidence of differences between initial and final parameters.

\section{Results of the researches}

On the base of systemic analysis of educational process organization we formed structural model of students' sport-oriented physical education with application of informational technologies. In the model all students are trained in sport-oriented academic groups by chosen kinds of sports (motor functioning). Such approach envisages holistic form of program material construction and unified algorithm of students' progress assessment.

Formation of academic groups by kinds of sports is a specific feature of sport-oriented physical education. Wholeness of sport-oriented physical education functioning is ensured by application of informational technologies. It permits to optimize training of motor skills. In this case single form of program material construction is created.

Usage of university's informational-communicative technologies is one of forms of informational technologies: university's, physical education department's, sport club's sites; organs of students' self-governing. The created by us Internet-site of physical education department plays key role in the research. The site contains the following information: scientific-pedagogic staff of the department; schedule of trainings with annotations of kinds of sports and references. The site is an informational technology of open type and is accessible for all students.

In experimental groups we used "closed" informational technologies for motor skills" training: animation video-programs with accentuated visualization of separate technical and tactic elements; films on principles of theory and methodic of the chosen kind of sports. Besides, we used printed manual with detail illustrations of techniques' video-grams. In experimental groups we used video-technologies for understanding of organism's work under physical load. It permitted to realize students' conscious approach to physical education classes. Thus, in the research we widely used methods of activation of conscious perception of motor actions. Demonstration of learning material was realized directly at practical classes.

In experimental group we observed confident increase of technical fitness results (see table 1):

- "Juggling with ball" from 25.47 times to $32.47 \mathrm{c}(\mathrm{t}=6.13, \mathrm{p}<0.001)$;

- "Kick to goal for distance" - from $28.26 \mathrm{~m}$ to $33.11 \mathrm{~m}(\mathrm{t}=7.23, \mathrm{p}<0.001)$;

- "Kick to pre-set sector of goal" - from 3.95 times to 6.95 times $(t=8.02, p<0.001)$;

- "Shuttle run $4 \times 10$ meters with ball" - from 12.22 sec. to 11.69 sec. $(\mathrm{t}=6.88, \mathrm{p}<0.001)$.

In control group there were also confident changes in indicators of tests "Juggling with ball" $(p<0.01)$ and "Shuttle run $4 \times 10$ meters with ball" ( $p<0.001)$. Dynamic of the rest of indicators was statistically not confident $(p>0.05)$. In experimental group we noticed improvement of results in tests: "Kick in pre-set sector of goal" (by 76\%, $\mathrm{t}=8.02$, $\mathrm{p}<0.001$ ); "Juggling with ball" (by 27.48\%, $\mathfrak{l}=6.13, \mathrm{p}<0.001$ ); "Kick to goal for distance" (by $17.13 \%, \mathfrak{t}=7.23, \mathrm{p}<0.001$ ). Minimal change of results was registered in test "Shuttle run $4 \times 10$ meters with ball" (by $4.31 \%, t=6.88, p<0.001)$. 
Table 1. Indicators of technical fitness of control group students $(n=21)$ and experimental group students $(n=19)$ before and after experiment

\begin{tabular}{|c|c|c|c|c|c|c|c|c|c|c|c|c|}
\hline Testing indicators & $\begin{array}{l}\text { Period of } \\
\text { testing }\end{array}$ & Group & $\bar{x}$ & $S$ & m & $\begin{array}{l}\text { Change } \\
\text { s \% }\end{array}$ & BE-AE & $\begin{array}{l}p \\
B E-A E\end{array}$ & $\begin{array}{l}\text { t } \\
\text { CG-EG } \\
\text { BE }\end{array}$ & $\begin{array}{l}p \\
\text { CG-EG } \\
B E\end{array}$ & $\begin{array}{l}\mathrm{t} \\
\mathrm{CG}-\mathrm{EG} \\
\mathrm{AE}\end{array}$ & $\begin{array}{l}\text { p } \\
\text { CG-EG } \\
\text { AE }\end{array}$ \\
\hline \multirow{4}{*}{$\begin{array}{l}\text { Juggling with ball, } \\
\text { times }\end{array}$} & $\mathrm{BE}^{*}$ & \multirow{2}{*}{$E G^{*}$} & 25.47 & 3.92 & 0.90 & \multirow{2}{*}{27.48} & \multirow{2}{*}{6.13} & \multirow{2}{*}{0.001} & \multirow{4}{*}{0.63} & \multirow{4}{*}{0.54} & \multirow{4}{*}{5.67} & \multirow{4}{*}{0.00} \\
\hline & $A E$ & & 32.47 & 3.06 & 0.70 & & & & & & & \\
\hline & BE & \multirow{2}{*}{ CG } & 26.10 & 2.21 & 0.48 & \multirow{2}{*}{6.93} & \multirow{2}{*}{2.80} & \multirow{2}{*}{0.01} & & & & \\
\hline & $A F$ & & 27.90 & 1.97 & 0.43 & & & & & & & \\
\hline \multirow{4}{*}{$\begin{array}{l}\text { Kick to goal for } \\
\text { distance, } m\end{array}$} & $B E$ & \multirow{2}{*}{ EG } & 28.26 & 2.23 & 0.51 & \multirow{2}{*}{-17.13} & \multirow{2}{*}{7.23} & \multirow{2}{*}{0.001} & \multirow{4}{*}{0.68} & \multirow{4}{*}{0.50} & \multirow{4}{*}{5.35} & \multirow{4}{*}{0.00} \\
\hline & $\mathrm{AF}$ & & 33.11 & 1.88 & 0.43 & & & & & & & \\
\hline & BE & \multirow{2}{*}{ CG } & 27.76 & 2.39 & 0.52 & \multirow{2}{*}{5.15} & \multirow{2}{*}{1.84} & \multirow{2}{*}{0.07} & & & & \\
\hline & $\mathrm{AF}$ & & 29.19 & 2.64 & 0.58 & & & & & & & \\
\hline \multirow{4}{*}{$\begin{array}{l}\text { Kick to pre-set } \\
\text { sector of goal from } \\
10 \text { meters' } \\
\text { distance (10 } \\
\text { attempts), quantity } \\
\text { of hits }\end{array}$} & $B E$ & \multirow{2}{*}{$E G$} & 3.95 & 1.18 & 0.27 & \multirow{2}{*}{76.00} & \multirow{2}{*}{8.02} & \multirow{2}{*}{0.001} & \multirow{4}{*}{0.37} & \multirow{4}{*}{0.72} & \multirow{4}{*}{7.39} & \\
\hline & $B E$ & & 6.95 & 1.13 & 0.26 & & & & & & & \\
\hline & $\mathrm{AF}$ & & 3.81 & 1.21 & 0.26 & & & & & & & 0.00 \\
\hline & $\mathrm{BE}$ & CG & 4.43 & 1.03 & 0.22 & 16.25 & 1.79 & 0.08 & & & & \\
\hline & $A F$ & $5 C$ & 12.22 & 0.25 & 0.06 & 121 & 600 & lo 001 & & & & \\
\hline Shuttle run $4 \times$ & BE & EG & 11.69 & 0.22 & 0.05 & 4.31 & 6.88 & 0.001 & 157 & $\ln 12$ & 536 & $\ln \cap 0$ \\
\hline with ball, sec. & $\mathrm{AF}$ & $C G_{-}$ & 12.36 & 0.31 & 0.07 & 216 & 307 & $\ln 01$ & & & & \\
\hline & $\mathrm{AE}$ & C & 12.10 & 0.25 & 0.05 & 2.10 & 3.07 & 0.01 & & & & \\
\hline
\end{tabular}

*Notes: BE- before experiment; AF - after experiment; CG - control group; EG - experimental group.

Experiment showed confident change of technical indicators in control group in tests "Shuttle run $4 \times 9$ meters with ball" (by $2.16 \%$, p $<0.001$ ) and "Juggling with ball" (by $6.93 \%$, p $<0.01$ ). Maximal change of technical fitness indicators in control and experimental groups was registered in test "Kick to pre-set sector of goal" $(16.25 \%)$. In test "Kick to gal for distance we registered change of indicators by $5.15 \%$. However, in control group these changes were not confident ( $\mathrm{p}>0.05)$.

\section{Discussion}

In works by L.N. Barybina [1;2] researches in higher educational establishments with sport-oriented physical education are described. The author offers algorithm of training process's individualization. Wide usage of these recommendations is possible exclusively in conditions of sport-oriented physical education. From this point of view our research confirms these data. From the point of view of informational technologies' application, in researches by Zh.L. Kozina et al. [7; 10] computer programs, permitting to quickly and effectively determine students' psycho-physiological characteristics are offered. In this aspect our research is a continuation and expansion of the offered results.

Our research also expands results of Zh.L. Kozina [8, 10] and S.S. Iermakov [4]. The authors substantiated effectiveness of development and application of informational technologies for ensuring of visibility in technical tactic training. In works of $\mathrm{Zh} . \mathrm{L}$. Kozina $[8,10]$ informational multi-media for application in sport functioning are studied. Our research is devoted to working out methodic of informational technologies' application in sphere of students' sport-oriented physical education.

Program provisioning can successfully be applied on all stages of students' perfection in chosen kind of sports (motor functioning). By it, results of our researches expands and supplements results of Zh.L. Kozina, L.N. Barybina [7]. Researches of these authors have been expanded and supplemented by the data of our work. Our work points at influence of informational technologies on students' physical and technical fitness. 
A number of authors $[11 ; 14]$ points that young people have great quantity of diseases. Unfortunately, correct eating and taking vitamins do not solve this problem. People can not eat ecologically pure products and live in areas with pure air and water.

The data of our research confirm and supplement results of V.A. Kashuba et al. [6] in respect to approaches and peculiarities of formation of students' demand in healthy physically active life style. Strategic purpose of higher education shall be creation of optimal medium. Such medium shall facilitate students' physical and moral improvement; preservation of actual health; formation of healthy life style habits; education of health culture. Theoretical approaches to the set problems' studying permit to mark directions of health related technologies' realization in higher educational establishments. It permits to determine their essence, components, criteria and directions of development $[5 ; 6 ; 12 ; 13]$.

In works of Kozina Zh.L. et al. [5] innovative technology of game-oriented aqua-fitness for integral influence on girl students' functional and psycho-physiological potentials is offered. Such technology includes: regulated rules of basketball in water with the help of technical equipment; methodic of training of movements in water for basketball in water; methodic of aqua-fitness exercises in combination with training of basketball [5].

It should be noted that application of progressive innovative technologies can be effectively realized in system of students' sport-oriented physical education. In this connection our research is a scientific-methodic basis for practical realization of modern progressive innovative technologies. In the same way our research is a scientific-methodic basis for realization of body-flex and Pilates methodic, presented in works of A.S. Ilnitskaya [18].

Comparison of the received data with results of other scientists' researches permits to formulate scientific novelty of our work in the following way.

In the work we supplemented and specified results of researches of S.S. Iermakov [4], Zh.L. Kozina et al. [15] in respect to advantage of sport-oriented form of physical education classes, comparing with traditional. It is expressed in students' higher interest in physical culture as well as in students' provisioning with the newest modern information about health perfection and physical fitness. In our research, for the first time we found positive influence of informational on students' physical fitness and on development of motor skills and abilities in chosen kinds of sports (on example of game kinds of sports).

The prospects of further researches imply determination of informational technologies' influence on HEE students' physical and technical fitness in chosen kinds of sports with sport-oriented physical education.

\section{Conclusions}

We have been substantiated ways of application of information technologies in sport-oriented physical education in higher educational establishments. Such approach envisages the following: working out and usage of physical education department's site and sites of sport clubs; application of printed editions, video and multi-media technologies.

Application of informational technologies confidently improves students' physical and technical fitness. Indicators in test "Juggling with ball", in test for distance of kick, for quantity of hits in pre-set sectors of goal and for speed of movements with ball confidently increased. In control group changes of these indicators was less expressed and in a number of cases they were not confident.

The received results confirm and prove purposefulness of information technologies' application in organization of sport-oriented physical education of higher educational establishments' students.

\section{Acknowledgements}

The research has been conducted in compliance with the following:

- $\quad$ "Combined plan of scientific-research works in sphere of physical culture and sports for 20112015 " by topic 2.4 "Theoretical-methodic principles of individualization in physical education and sports" (state registration № 0112U002001);

- $\quad$ Scientific research work of Ministry of education and science of Ukraine for 2013-2014 "Theoretical-methodic principles of application of informational, pedagogic and medical-biological technologies for formation of healthy life style” (State registration № 0113U002003)

- $\quad$ Scientific-research work of Ministry of education and science of Ukraine for 2015-2016 "Theoretical-methodic principles of application of means of informational, pedagogic and medical-biological 
orientation for motor and mental development and formation of healthy life style” (State registration № 0115U004036).

\section{Conflict of interests}

The authors declare that there is no conflict of interests.

\section{References:}

1. Barybina LN. Vliianie primeneniia sistemy individualizacii fizicheskogo vospitaniia v vysshem uchebnom zavedenii na funkcional'noe sostoianie studentok [Influence of application of physical education individualization system in higher educational establishment on girl students' functional state]. Pedagogics, psychology, medical-biological problems of physical training and sports, 2012;10:10-15. (in Russian)

2. Barybina LN, Kozina ZhL, Grin' LV. Psikhofiziologicheskie vozmozhnosti i ob"em vospriiatiia studentov raznykh sportivnykh specializacij [Psychological potentials and volume of perception of different sport specializations students]. Zdorov'esberegaiushchie tekhnologii, fizicheskaia reabilitaciia $i$ rekreaciia $v$ vysshikh uchebnykh zavedeniiakh, 2010;1:19-21. (in Russian)

3. Borisov VV, Olejnik ON, Timoshenko VV. Motivacionnoe obespechenie uchebno-vospitatel'nogo processa $\mathrm{s}$ ispol'zovaniem tekhnologii sportivno-orientirovannogo fizicheskogo vospitaniia $\mathrm{v}$ vuze [Motivational provisioning of educational process with application of technology of sport-oriented physical education in HEE]. Molodoj uchenyj, 2014;17:459-461. (in Russian)

4. Iermakov SS, Ivashchenko SN, Guzov VV. Osobennosti motivacii studentov s primeneniem individual'nykh programm fizicheskoj samopodgotovki [Specificities of students' motivation with application of individual physical education self-training programs]. Physical education of students, 2012;4:59-61. (in Russian)

5. Kozina ZhL, Iermakov SS, Bazyliuk TA, Voloshina EV Innovacionnye tekhnologii akvafitnesa igrovoj napravlennosti $\mathrm{s}$ primeneniem tekhnicheskikh ustrojstv $\mathrm{v}$ fizicheskom vospitanii studentok [Innovative technologies of game-oriented aqua-fitness with application of technical means in girl students' physical education]. Physical education of students, 2012;1:42-47. (in Russian)

6. Kashuba VA, Futornyj SM, Golovanova NL. K voprosu ispol'zovaniia informacionnykh tekhnologij v processe fizicheskogo vospitaniia studencheskoj molodezhi [On the problem of informational technologies' application in process of students' physical education]. Slobozhans'kij naukovo-sportivnij visnik, 2011;4:157163. (in Russian)

7. Kozina ZhL, Barybina LN. Kharakteristika psikhofiziologicheskikh pokazatelej studentov razlichnykh sportivnykh specializacij [Characteristic of different sport specialties students' psycho-physiological indicators]. Physical education of students, 2010;4:38-47. (in Russian)

8. Kozina ZhL. Avtorskie informacionnye, pedagogicheskie i mediko-biologicheskie tekhnologii dlia formirovaniia zdorovogo obraza zhizni [The author's informational, pedagogic and medical-biological technologies for formation of healthy life style]. Visnik Chernigivs'kogo derzhavnogo pedagogichnogo universitetu, 2013;3:44-48. (in Russian)

9. Kozina ZhL. Faktorni modeli fizichnoi pidgotovlenosti volejbolistok visokogo klasu riznogo igrovogo amplua [Factorial models of different game roles elite female volleyball players' physical fitness]. Pedagogics, psychology, medical-biological problems of physical training and sport, 2007;9:80-85. (in Ukrainian)

10. Kozina ZhL, Cerkovna OV, Vorobjova VO. Viznachennia efektivnosti zmagal'noi diial'nosti v basketboli za dopomogoiu zastosuvannia informacijnikh tekhnologij [Determination of competition functioning effectiveness in basketball with the help of information technologies' application]. Slobozhans'kij naukovosportivnij visnik, 2008;1-2:151-158. (in Ukrainian)

11. Ol'khovij OM. Dinamika fizichnogo stanu iunakiv 17-22 rokiv u procesi profesijno-prikladnoi fizichnoi pidgotovki [Dynamic of 17-22 years' age boys' physical condition in process of professional-applied physical training]. Sportivnij visnik Pridniprov'ia, 2014;1:219 - 224. (in Ukrainian)

12. Temchenko VA, Sirenko RR. Sekcionnaia forma organizacii fizicheskogo vospitaniia studentov [Sport-circle form of organization of students' physical education]. Physical education of students, 2010;3:99-101. (in Russian)

13. Temchenko VA, Petrenko IuM, Makhonin IN. Ocenivanie uspevaemosti studentov, zanimaiushchikhsia futzalom [Assessment of progress of students, who practice football indoors]. IX mezhdunarodnaia nauchnaia 
konferenciia, 8-9 fevralia 2013 goda "Problemy i perspektivy razvitiia sportivnykh igr $i$ edinoborstv $v$ vysshikh uchebnykh zavedeniiakh" [9th international scientific conference, February 8-9, 2013 "Problems and prospects of sports games and martial arts development in higher educational establishments"], 2013; P. 341-345. (in Russian)

14. Futornyj CM, Kashuba VA. Rol' fizicheskogo vospitaniia i sporta v orientacii studentov na zdorovyj obraz zhizni [Role of physical education and sports in orientation of students for healthy life style]. Physical education of students, 2011;3:94-98. (in Russian)

15. Kozina ZhL, Barybina LN, Lugina IV, Kozin AV. Eksperimental'noe obosnovanie sistemy individualizacii v fizicheskom vospitanii studentov [Experimental substantiation of individualization system in students' physical education]. Physical education of students, 2012;4:77-86. (in Russian)

16. Toke S. Aidt, Bernard Leong, William C. Saslaw, Daniel Sgroi. A power-law distribution for tenure lengths of sports managers. Physica A: Statistical Mechanics and its Applications, 2006;370(2,15):697-703.

17. Roberto da Silva, Mendeli H Vainstein, Luis C Lamb, Sandra D Prado. A simple non-Markovian computational model of the statistics of soccer leagues: Emergence and scaling effects. Computer Physics Communications, 2013;184(3):661-670.

18. Ilnitskaya AS, Kozina ZL, Barybina LN, Kolomiez NA, Cieślicka Mirosława, Stankiewicz Błażej, Pilewska Wiesława. Author's internet blog as information and communication technologies in the educational space within the physical education students. Physical education of students, 2014;1:22-26. http://dx.doi.org/10.6084/m9.fgshare.903689

19. Burrows L, McCormack J. School culture meets sport: A case study in New Zealand. European Physical Education Review, 2011;17:301-312.

20. Connolly J, Dolan P. Sport, media and the Gaelic Athletic Association: the quest for the «youth» of Ireland. Media Culture Society, 2012;34:407-423.

21. Peker K, Bermek G. Predictors of Health-Promoting Behaviors Among Freshman Dental Students at Istanbul University. J Dent Educ., 2011;75:413-420.

22. Dzikus L, Hardin R, Waller SN. Case Studies of Collegiate Sport Chaplains. Journal of Sport and Social Issues, 2012;36:268-294.

23. Goumas C. Modelling home advantage in sport: a new approach. Int J Perf Anal Sport, 2013;13:428439.

24. Kaufman P, Wolff EA. Playing and Protesting: Sport as a Vehicle for Social Change. Journal of Sport and Social Issues, 2010;34:154-175.

25. Kerr R. Integrating Scientists into the Sports Environment: A Case Study of Gymnastics in New Zealand. Journal of Sport and Social Issues, 2012;36:3-24.

26. Roseli AF Romero, Edson Prestes, Marco AP Idiart, Gedson Faria. Locally oriented potential field for controlling multi-robots. Communications in Nonlinear Science and Numerical Simulation, 2012;17(12):46644671 .

27. Page L, Page K. The second leg home advantage: evidence from European football club competitions. J Sports Sci, 2007;25:1547-1556.

28. Murphy MH, Donnelly P, Shibli S, Foster C, Nevill AM. Physical activity, walking and leanness: An analysis of the Northern Ireland Sport and Physical Activity Survey (SAPAS). Preventive Medicine, 2012;54 (2): $140-144$.

29. Pollard R. Worldwide regional variations in home advantage in association football. J. Sports Sci, 2006;24:231-240.

30. Roberto da Silva, Silvio R. Dahmen Universality in the distance between two teams in a football tournament. Physica A: Statistical Mechanics and its Applications, 2014;398(15):56-64.

31. Stefanie P, Petra J. Different mental rotation performance in students of music, sport and education. Learning and Individual Differences, 2012;9(22,1):159-163.

32. Ilnitskaya AS, Kozina ZhL, Lakhno EG, Ilnitskaya LV, Cieślicka Mirosława, Stankiewicz Błażej, Pilewska Wiesława. Students' attitude to the possibility of applying modern information and communication 
technologies in the educational process in physical education. Physical education of students, 2014;2:18-24. http://dx.doi.org/10.6084/m9.fgshare.906369

33. Tucker P, Irwin JD. University Students' Satisfaction With, Interest in Improving, and Receptivity to Attending Programs Aimed at Health and Well-Being. Health Promot Pract, 2011;12:388-395.

34. Wakefield CJ, Adie JW. Evaluating sport psychology teaching through action research. Journal of Hospitality, Leisure, Sport \& Tourism Education, 2012;11(2):125-130.

35. Marchwant Przemysław, Cieślicka Mirosława, Muszkieta Radosław, Zukow Walery, Iermakov Sergii. The impact of training on the efficiency overall and special players Youth Sports Training Center in Bydgoszcz and MLKS Wlokniarz Okonek [Wpływ treningu na sprawność ogólną i specjalną piłkarzy Ośrodka Szkolenia Sportowego Młodzieży w Bydgoszczy i MLKS Włókniarza Okonek]. Journal of Education, Health and Sport, 2015; 5(5):463-486. http://dx.doi.org/10.5281/zenodo.18158 (in Polish) 


\begin{abstract}
Information about the authors:
Kozina Zh. L.; http://orcid.org/0000-0001-5588-4825;

Zhanneta.kozina@gmail.com; H.S. Skovoroda Kharkiv National Pedagogical University; Artema str. 29, Kharkov, 61002, Ukraine.

Ol'khovyj O. M.; http://orcid.org/0000-0002-5223-5229; skZirka@email.ua; Kharkov National University; Liberty pl. 4, Kharkov, 61077, Ukraine.

Temchenko V. A.; http://orcid.org/0000-0003-0171-4614; temchenko1961@mail.ru; Kharkov National University; Liberty pl. 4, Kharkov, 61077, Ukraine.

Cite this article as: Kozina Zh.L., Ol'khovyj O.M., Temchenko V.A. Influence of information technologies on technical fitness of students in sport-oriented physical education. Physical education of students, 2016;1:21-28. doi:10.15561/20755279.2016.0103

The electronic version of this article is the complete one and can be found online at: http://www.sportpedu.org.ua/html/arhive-e.html

This is an Open Access article distributed under the terms of the Creative Commons Attribution License, which permits unrestricted use, distribution, and reproduction in any medium, provided the original work is properly cited (http://creativecommons.org/licenses/by/4.0/deed.en).
\end{abstract}

Received: 03.02.2016

Accepted: 22.02.2016; Published: 25.02.2016 